\section{Physic and Literature}

UNDER the title of "Books about the Doctor in Physick and Literature", Schuman's of 738 Fifth Avenue, New York, have published an annotated spring catalogue consisting of five parts devoted respectively to medicine in literature, medical biography, history of medicine, medical portraits and Beaumont lectures. The first part, which will probably appeal to the largest number of readers, contains a long list of belles lettres which have reference to medicine, including in alphabetical order Aristotle's masterpiece, Balzac's "Médecin de Campagne", Sir Thomas Browne's "Urn Burial", Burton's "Anatomy of Melancholy", Casanova's "Mémoires", Defoe's "Journal of the Plague Year", Pepys's "Diary", plays of Shakespeare, and Voltaire's "Candide". The relation of medicine to art is represented by Leonardo da Vinci's drawings and the works of Eugen Holländer. The works on medical biography include those of Bland-Sutton, Jerome Cardan, Harvey Cushing, Sir Henry Holland, Edward Jenner, William MacMichael and Thomas Young. Under the heading of medical history we find works by Allbutt on Greek medicine in Rome, Donald Campbell and Leclere on Arabian medicine, W. G. Black on folk-medicine, Sir Michael Foster on the "History of Physiology during the Sixteenth to Eighteenth Centuries", August Hirsch on "Geographical and Historical Pathology", Osler on the "Evolution of Modern Medicine", J. F. Payne on "English Medicine in the Anglo-Saxon Times", and histories of medicine by Max Neuburger and Sudhoff.

\section{Earthquake in Tibet}

ON July 15 an earthquake of considerable severity accompanied by floods was reported in The Times to have caused havoc in the Chumbi Valley in southern Tibet. Villages from Yatung southwards suffered considerable damage, and the telegraph line from Yatung to India over a distance of six miles has been destroyed. All the bridges over the Amachu River have been demolished and, in all, two hundred people are believed to have perished. The epicentre appears to have been near lat. $27 \cdot 5^{\circ} \mathrm{N}$., long. $89^{\circ} \mathrm{E}$., which is a little to the south of the epicentre of the strong earthquake of January 3, 1935, and to the south-west of that of January 7, 1937.

\section{Earth Tremors in Great Britain}

ON Sunday, July 14, at about 11.59 p.m. B.S.T. a slight earth tremor was felt in Birmingham, Coventry and Leicester. No damage was done. The epicentre was probably just to the north of Coventry. Earth tremors appear to be slightly more frequent in an area somewhat to the north of Leicester, that is, nearer to Nottingham, where one was experienced on May 3, 1935, though one was felt at Birmingham on October 23,1924 . On July 16 at about 5.35 p.m. B.S.T. an earth tremor lasting several seconds was felt very strongly in the Denny district of Stirlingshire and for some miles around. In the epicentral area, a man is reported to have been thrown from his chair. The shock threw crockery from shelves and moved chairs and desks in Glasgow offices; it was felt more strongly at the top of high buildings than in the street below. No serious damage has been reported. Slight earth tremors are very occasionally felt in this district, though the area most affected by earth tremors in Scotland is near Comrie in Perthshire, where the British Association has shock recorders in action. Both the recent Coventry and Denny tremors were probably caused by slipping along local fault systems.

\section{The Night Sky in August}

New moon occurs on August 3 at $20 \mathrm{~h}$. and full moon on August 17 at 23h. U.T. The moon is in conjunction with Mercury on August 2, with Saturn and Jupiter on August 24, and with Venus on August 29. Jupiter and Saturn rise after $22 \frac{1}{2} \mathrm{~h}$. at the beginning of the month and shortly after $21 \mathrm{~h}$. at the end, the two planets remaining within $1 \frac{1}{2}^{\circ}$ of each other. Although conjunction between them occurs on August 15, their elosest approach $\left(1 \cdot 2^{\circ}\right)$ is on August 7. Venus is the brilliant morning star, at greatest brilliancy on August 2, when it rises shortly before $1 \mathrm{~h} .45 \mathrm{~m}$. U.T. At the time of conjunction with the moon on August 29, it may be looked for in daylight north of the moon. A telescopic view of the planet will show it to be crescent-shaped throughout the month. Mercury, an elusive object at most times, should be easily seen in the east before sunrise, especially on August 10 when it reaches its greatest elongation ( $19^{\circ}$ west). On August $10-12$, the Perseid meteors reach their maximum frequency. Their radiant point moves from Andromeda to Camelopardus. The Milky Way and its associated constellations, rich in interesting objects for telescopic or binocular study, is well placed near the meridian after dark, especially towards the end of August, when the moon does not rise until the early morning.

\section{Announcements}

Dr. William W. Watson has been appointed professor of physics in Yale University, in succession to Prof. John Zeleny, who retires this year.

THE degree of D.Sc. has been awarded by the Queen's University, Belfast, to R. C. Pink (chemistry) and C. T. Ingold (botany).

THE National Council for Mental Hygiene, 76 and 77 Chandos House, Palmer Street, London, S.W.1, has arranged for a conference to be held on July 30 at the British Medical Association House, Tavistock Square, W.C.1, to discuss psychological problems arising out of war conditions as they affect the teacher.

THE first volume in Braille dealing with botany has been prepared from a series of broadcasts on "Botany for the Amateur" made in the United States by Miss Jesse Fiske, State seed analyst of the New Jersey Experimental Station, New Brunswick. 